\title{
MARKETING COMMUNICATION INNOVATION OF FRESH FRUIT AND VEGETABLES (FFV) MODERN RETAIL LOCAL SUPPLIER: COMPETITIVENESS OF SMALL HOLDER TO ENTER MODERN RETAIL
}

\author{
Hesty Nurul Utami and Agriani Hermita Sadeli \\ Department of Agribusiness, Faculty of Agriculture, Universitas Padjadjaran \\ Jalan Raya Bandung Sumedang KM.21, Jatinangor 45363 \\ Email: hestyutami@gmail.com;
}

\begin{abstract}
Modern retail rapid development is an opportunity for fruit and vegetable farmers to fulfill consumer retail business demand. This research give an insight of how marketing communication innovation suggested for local FFV supplier in order to enter modern retail by concerning their competitiveness through modern retail point of view and adjusted with modern retail marketing decision. It applies qualitative design through case study at Retail XYZ Group. The main FFV supplier criteria appointed by the company are supplier price product offering, product quantity, quality and continuity. Overall, almost all of local FFV supplier marketing criteria is perceived worst than importer in terms of durability, quantity, service level, after post harvest handling, R\&D, and commodity attribute. An incremental marketing communication innovation could be done via direct partnership with small holders who are able to meet retail FFV requirements in commodity quantity, quality, continuity, post harvest handling, durability, research and development facility, product sourcing and availability throughout season, and deliver service excellent. This is an opportunity for the small holder to build a long term relationship marketing with modern retail.
\end{abstract}

Keywords: marketing, communication, innovation, modern retail, supplier

\section{KOMUNIKASI PEMASARAN INOVASI BUAH SEGAR DAN SAYURAN (FFV) MODERN PEMASOK LOKAL ECERAN: DAYA SAING PEMEGANG KECIL UNTUK ENTER RETAIL MODERN}

ABSTRAK. Perkembangan ritel modern merupakan sebuah peluang bagi petani buah dan sayuran untuk turut berkontribusi memenuhi permintaan ritel modern. Penelitian ini memberikan gambaran mengenai inovasi komunikasi pemasaran bagi suplier lokal buah dan sayuran untuk memasuki pasar ritel modern berdasarkan persepsi modern ritel terhadap kinerja pemasaran supplier buah dan sayuran dan menyesuaikan dengan strategi pengambilan keputusan pemasaran buah dan sayuran ritel modern. Penelitian ini mengaplikasikan desain penelitian kualitatif melalui studi kasus terhadap Ritel XYZ Group. Persepsi ritel terhadap seluruh kriteria pemasaran yang dimiliki oleh suplier lokal buah dan sayuran dipersepsikan lebih buruk dibandingkan importir buah dan sayuran dalam hal ketahanan produk, kuantitas suplai, tingkat pelayanan, pengananan paska panen, riset dan pengembangan, dan atribut komoditas. Inovasi komunikasi pemasaran yang inkremental dapat dilakukan melalui bermitra dengan petani buah dan sayuran yang memiliki kriteria mampu memenuhi permintaan kuantitas, kualitas, penanganan paska panen, ketahanan, riset dan pengembangan, kemudahan pencarian produk, ketersediaan komoditas sepanjang musim, dan pelayanan yang memuaskan. Hal ini dapat menjadi peluang bagi petani buah dan sayuran lokal untuk menjadi rekanan ritel modern dan manjalin hubungan pemasaran jangka panjang.

Kata kunci: pemasaran, komunikasi, inovasi, ritel modern, suplier

\section{INTRODUCTION}

Business competition between traditional and modern retail in Indonesia are very tight these days. The condition could not be separated from the fact that Indonesia consumer are now begin to be more interest to shopping at modern retail. This is consistent within shopping patterns changes of modern society; the family went shopping to a complete outlet with one stop shopping concept and provides convenience. Consumer lifestyle affects their expenditure patterns of modern society who expect comfort, cleanliness and efficient while doing shopping and this condition is abandoned by consumer of traditional market. (Abdullah, 2003). It is also along with Kovacic et.al (2002), that visiting a market is a cultural activity for people in a urban area and its part of general lifestyle.

Society shopping patterns which shifted from traditional to modern market has been growth quite high from 2004 to 2008. Hypermarket gained the highest outlet sales among other modern market and then followed by mini-and supermarkets (Pandin, 2008).

In 2008 there were five modern retailing with hypermarket category and six categories of supermarkets that dominate the Indonesian market (Rangkuti \& Slette, 2010). The increasing number of retail industry players is certainty brings a more competitive business environment. This situation brings consequences for the retail player to create an innovative business strategy.

One of the biggest retail with supermarket category is Retail XYZ Group with 10.61 percent share in 2008 and gain the $6^{\text {th }}$ rank over 15 biggest supermarkets in Indonesia (Pandin, 2008). Retail XYZ Group show as the largest and strongest regional retailer with aggressive and expansive which mostly operates in West Java (Kanjaya, 2010). This retail business growth every year and also has been expanded to various type of retail store. Retail XYZ Group comes with several formats ranging from department stores and supermarkets (Kanjaya, 2010). 
Fresh food in the supermarket business has a high risk compared with the other products. Only a few of supermarkets in Indonesia have a good fresh product turnover. Furthermore, if supermarkets could sell fresh food with good turnover it is likely that many consumers will come to buy the fresh food (Kanjaya, 2010).

Fruits and Vegetables is one of the fresh foods that have a high risk of damage. According to Labaste (2005), characteristic of horticultural products especially for fresh consumption, has a high perishable nature and the relatively high value volume. Although horticultural products are high risk products, it has a very large market opportunity. Through modern retail market opportunities which currently grows rapidly, especially in offering new opportunities to improve the bargaining position of small holder to compete in filling the market opportunities. FFV in modern retail not only fulfill by local supplier but also importer of FFV products. Therefore, local FFV farmers who sell their product to modern retail should have a high competitiveness in order to be more attractive to the modern retail and give other option for modern retail of FFV sourcing. Hence to apprehend this opportunity so that modern retail will then purchase local FFV products, it can be done through innovation.

Innovation is a detection and fulfillment of unfilled wants of potential customers. This suggests that successful companies are likely to have strong marketing skills in the language of the marketing profession, they will have a high degree of market orientation a concept usually measured by the extent that a company bases its activities on information about consumers, through collecting relevant data, digesting it, disseminating it within the company and reacting to it (Kohli and Jaworski, 1990 in Traill, 2002).

An important strategic option for companies that want to remain in the top of the industry is to pursue a prospector strategy which brings continuous streams of innovative new products to the market or implements new processes before competitors do (Miles and Snow, 1987). ARapid changing on customer behavior gives consequences for the company to keep innovative continuously. An innovative business actor with a good marketing performance can bring a bigger competitive advantage.

It is stated that marketing and communications of a business company are a major and persuasive element of an organization that can be use to bridge with the market by delivering and communicating ideas then become the first step to build a certain perception toward business product (Porcu et.al, 2012). This means that company should be able to interpreted costumer needs and wants into company product. Therefore it is substantial to develop a relationship through marketing communication between FFV supplier and modern retail. Thru a structured communication, whether producers and costumer will be able to interact dynamically each other and gain a mutual benefit for both.

Furthermore, marketing communication innovation is not only eternally a breakthrough in exercising something, but in some way it can a form of renewal or alteration (Masterman and Wood, 2005). So that creating a new way of an incremental marketing communication is also considered as an innovation to gain a better competitiveness. Therefore, this research give an insight of how marketing communication innovation suggested for local FFV supplier in order to enter modern retail by concerning their competitiveness through modern retail point of view and adjusted with modern retail marketing decision.

\section{METHOD}

This research is done at Retail XYZ Group as one of the biggest local retail in West Java. Qualitative research method was applied with case study design. Data collection conducting were through interview with five company management, there are Retail XYZ Group Chief Operation and four personnel of buyer division of fresh product, two buyer personnel each for local and import fresh fruit and vegetable in order to determine retail marketing strategy for fresh fruit and vegetable product on the next five years; through primary data based on closed questionnaire concerning on retail perception of supplier marketing whether local or import FFV supplier; through retail field observation; and through other complementary secondary data.

From the result of interview of company management, then supplier marketing evaluation criteria was build for the questionnaire, both for local and import fresh fruit and vegetables supplier. By using likert scale in four range of category 1 to 4 , then respondents need to evaluate the marketing of FFV supplier. The questionnaire result interpretation is through linier numeric of scale by giving a score or scale where the score of one was concern as negative pole, and score of four was as positive pole. Afterwards, specify the score range which is 0.75 with four categories as shown below:

Table 1. Scale Range and Qualification Variable

\begin{tabular}{cc}
\hline Scale Range & Qualification \\
\hline $4>_{\mathrm{x}}>=3,25$ & Perfect \\
$3,25>_{\mathrm{x}}>=2,5$ & Good \\
$2,5>\mathrm{x}>=1,75$ & Ordinary \\
$1,75>\mathrm{x}>=1$ & Bad \\
\hline
\end{tabular}

\section{RESULT AND DISCUSSION}

\section{FFV Product of Retail XYZ Group}

Fresh products sales contribution target especially in subsidiaries stores at big cities with lifestyle and superstore format is rise up to $40 \%-50 \%$ with fresh product contribution approaching $15 \%-17 \%$. It is forecasting to be increase in every year. This is one the impact of consumer shopping behavior changes that are now more like to shop their needs on fresh product in modern retail such as supermarket or hypermarket rather than in traditional market. 
Product procurement neither for local or import FFV are apply forward purchasing system, made by contractual letter between retail and supplier deal which specify product quantity, quality, payment system with competitive price. This strategy is considered better for its guarantee in product availability and continuity rather than spot market mechanism which giving a huge possibility of uncertainty risk in supplier sourcing cost, product availability and continuity. Spot market mechanism successfulness depends on procurement division to get the appropriate supplier.

The company has cooperate with dozen of FFV local supplier, whether a supplier which also a farmer (producer) or a trader supplier. They also partnering with five importers for FFV products who supplied the product to all subsidiaries store. The company also have fresh product division and auction division who responsible for product procurement, product buying, supplier and product sourcing, and also screaming potential supplier.

\section{Retail XYZ Group Marketing Decision Matrix Change For FFV}

Marketing as part of a firm business function that could be use as one of firm strategy in order to compete and survive in business competition (Kohli and Jaworski, 1990). Indonesian business retail indeed offers a good prospect with its huge market potential (Sopiah \& Syihabudhin, 2008).

Nowadays, Modern retail store become Indonesian consumer choice to fulfill their daily needs especially for food is now emerge in various store types. This also affect to FFV provision availabilities and its marketing program and strategy.

The existing of small holder of FFV at Retail $\mathrm{XYZ}$ Group is already been supplied since fresh product becoming one of their supreme product. It shows by the embrace of small holder in West Java and East Java who become supplier of tomatoes, durian, and mangoes. The increasing of FFV demand at every Retail XYZ Group subsidiaries store is one of the reasons for the company to finally decide to use small holder to be their supplier in order to fulfill the insufficiency supply from the other supplier. However, Retail XYZ Group has certain policy for FFV small holder who become their direct supplier only for those who able to fulfill company requirements for the fresh fruit and vegetables concerning product quantity, quality, and continuity.

One of marketing concepts is concerned with change but in a more orderly structured way (Stokes, 2000). Along with the statement, This mean that consumer requirements on FFV have been change since modern retail market has appeared to be one of their choices to shop. Modern retail is a reflection of socio economic, culture, and lifestyle changes. It charges a higher and better product demand by the costumers. If the company failed to fulfill consumer needs and wants will lead them to fail in loose in the business.
Marketing is also an organizational philosophy, which relies that marketing is a set of value and beliefs with costumer as central point to the success of the organization (Kohli \& Jaworski, 1990) It shows that how a customer or market orientation is one of key success of the company. To reflect costumer needs and wants, Retail XYZ Group has an organized plan with their FFV product existence marketing strategy and how it might change due to marketing environmental changes.

Table 2. Marketing Strategy Decision Matrix Change in Retail XYZ Group Modern Retail for Fresh Fruit and Vegetables (FFV) Product

\begin{tabular}{|c|c|}
\hline $\begin{array}{l}\text { Company } \\
\text { Decision } \\
\text { Marketing } \\
\text { Strategy }\end{array}$ & $\begin{array}{ll}\text { - } & \text { Rise up FFV sales contribution } \\
\text { - } & \text { Direct sourcing to local and foreign production center of } \\
\text { FFV for high demand } \\
\text { - } & \text { FFV variety provided based on market potential at every } \\
\text { - } & \text { subsidiary store } \\
\text { - } & \text { Some local fruits are salemore expensive than import fruits } \\
\text { by means of its cost } \\
\text { - } \quad \text { Some local FFV are provided by local importer } \\
\text { - Some fresh products distribute from distribution centre } \\
\text { (DC) } \\
\text { Some exotic fruits only sale at lifestyle store, due to its } \\
\text { skimming price with high-end customer. }\end{array}$ \\
\hline $\begin{array}{l}\text { Local FFV } \\
\text { Opportunity to } \\
\text { Access Retail } \\
\text { XYZ Group }\end{array}$ & $\begin{array}{l}\text { - } \\
\text { hompany has nowbegin to employ horticulture small } \\
\text { - } \\
\text { FFV has now become one of retail supreme product } \\
\text { Horticulture small holder are now considered to become } \\
\text { company business partner to fulfill the higher of fresh } \\
\text { product needs and demand. }\end{array}$ \\
\hline $\begin{array}{l}\text { Company } \\
\text { Marketing } \\
\text { Strategy Future } \\
\text { Planning }\end{array}$ & $\begin{array}{l}\text { - } \\
\text { Add more lifestyle genre and superstore type in with more } \\
\text { FFV provision and variety of especially local exotic fruit } \\
\text { Gain more local supplier and importer to fulfill their needs } \\
\text { of exotic FFV in the future } \\
\text { - } \quad \text { Sourcing more FFV from local supplier closer to subsidiary } \\
\text { store and distribute it directly without thru DC. } \\
\text { Farmer direct partnership will only be done with farmers } \\
\text { who are capable of meet retail requirements }\end{array}$ \\
\hline
\end{tabular}

Data Processed, 2012

Retail XYZ Group future planning for their marketing strategy for the next five years in general is to keep doing sourcing for the best FFV product which considered as product with high potential market. It is done in order to add FFV product variety for each store type and quest to find FFV producers directly from their place of origin whether for FFV local or import. Nevertheless, it should be feasible with company financial planning including FFV product provision cost and price. In seeking out markets for agricultural products, it is often a good idea to start locally (Phillips and Peterson, 2007). This means that Retail XYZ Group marketing strategy for FFV is now shifted and focus on market and consumer behavior changes and mapping the appropriate marketing in next several years with the involvement of FFV producers not just the supplier. Food safety and traceability system are also market determinants in agribusiness vegetables international trade (Perdana, 2009).

Direct product sourcing from the foreign farmers is recognized to be cheaper in price rather than buy it from the national importer. This strategy is already begin by doing product sourcing for durian fruit directly from Thailand without through the importer, 
and several fresh fruit local from local farmer in West Java and Central Java. The company hopes to get a high quality of supplier which able to supply their FFV to the retail as the consequences of the more costumers prefers to go the modern retail. This is also an opportunity for FFV producers to be direct retail supplier; and does not rule of the possibility for small holder as long as they can fulfill retail requirement.

\section{Modern Retail Perception towards Marketing of FFV Supplier}

According to the management of assessment of Retail XYZ Group, overall supplier evaluation criteria for supplier performance FFV imports have better marketing than the local FFV suppliers in almost all marketing criteria are assessed. Retail XYZ Group needs a supply that can keep pace with the FFV demand from consumers. Suppliers that fill the needs of the supply must have a good service. The successful marketing of the product is determined by whether or not the services provided by a company in marketing their products (Assauri, 2010). Local FFV supplier service level is worse than the FFV imported suppliers. This is reflected in the ability of local suppliers to meet demand quantity of the product in accordance with the Yogya much better on supplier FFV imports than local suppliers.

Table 3. Modern Retail Perception towards FFV Supplier arketing

\begin{tabular}{|c|c|c|c|c|}
\hline \multirow{2}{*}{$\begin{array}{l}\text { Marketing } \\
\text { Criteria }\end{array}$} & \multicolumn{2}{|c|}{$\begin{array}{c}\text { Supplier Rating } \\
\text { Average }\end{array}$} & \multicolumn{2}{|c|}{ Supplier Qualification } \\
\hline & Local & Import & Local & Import \\
\hline Service level & 1.5 & 2.5 & $\mathrm{Bad}$ & Good \\
\hline $\begin{array}{l}\text { Fulfillment } \\
\text { capabilities of } \\
\text { FFV demand }\end{array}$ & 1.5 & 2.5 & $\mathrm{Bad}$ & Good \\
\hline FFV quality & 2.5 & 3 & Good & Good \\
\hline FFV durability & 1.5 & 2 & $\mathrm{Bad}$ & Ordi-nary \\
\hline $\begin{array}{l}\text { FFV post } \\
\text { harvest } \\
\text { handling }\end{array}$ & 1.5 & 2.5 & $\mathrm{Bad}$ & Good \\
\hline R\&D Facility & 1.5 & 2 & $\mathrm{Bad}$ & Ordi-nary \\
\hline $\begin{array}{l}\text { Supplier } \\
\text { knowledge }\end{array}$ & 2.5 & 3.5 & Good & Good \\
\hline FFV packaging & 2 & 3 & Ordi-nary & Good \\
\hline $\begin{array}{l}\text { FFV production } \\
\text { Volume/provisi } \\
\text { on }\end{array}$ & 2 & 2.5 & Ordi-nary & Good \\
\hline $\begin{array}{l}\text { Product } \\
\text { sourcing } \\
\text { easiness }\end{array}$ & 1.5 & 2 & $\mathrm{Bad}$ & Ordi-nary \\
\hline $\begin{array}{l}\text { Availability of } \\
\text { FFV } \\
\text { throughout } \\
\text { season }\end{array}$ & 1 & 1.5 & $\mathrm{Bad}$ & Bad \\
\hline $\begin{array}{l}\text { FFV supply } \\
\text { forecasting } \\
\text { accuracy }\end{array}$ & 1.5 & 2.5 & $\mathrm{Bad}$ & Good \\
\hline $\begin{array}{l}\text { Easiness in } \\
\text { product storage }\end{array}$ & 2 & 3 & Ordi-nary & Good \\
\hline $\begin{array}{l}\text { Availability of } \\
\text { storage }\end{array}$ & 1.5 & 2.5 & $\mathrm{Bad}$ & Good \\
\hline $\begin{array}{l}\text { Timeliness of } \\
\text { orders }\end{array}$ & 1.5 & 2.5 & $\mathrm{Bad}$ & Good \\
\hline $\begin{array}{l}\text { Complaint } \\
\text { handling }\end{array}$ & 2 & 2.5 & Ordi-nary & Good \\
\hline $\begin{array}{l}\text { Technical } \\
\text { assistance for } \\
\text { FFV handling }\end{array}$ & 1.5 & 2 & $\mathrm{Bad}$ & Ordi-nary \\
\hline $\begin{array}{l}\text { Shipping costs } \\
\text { incurred }\end{array}$ & 2.5 & 3 & Good & Good \\
\hline Price of FFV & 2.5 & 3 & Good & Good \\
\hline Promotions & 1.5 & 2.5 & $\mathrm{Bad}$ & Good \\
\hline
\end{tabular}

Source: Data Processed, 2012
Provision of local FFV quantity is perceived worse than imported FFV. FFV provision on supplier is affected by the level easiness of FFV sourcing supplied to retail and availability of storage space such as warehouse storage at the supplier. FFV procurement in accordance with the desired quality of Retail XYZ Group in FFV import is easier than FFV local. Hence to the production capacity of local FFV farming are still not good enough, especially from small farmers. FFV local small farmers have some limitations and problems in terms of education, lack of capital and limmited land area. In terms of production, technology owned by local FFV pertain not have high technology to tackle climate change dynamics. FFV small farmers who deals only in the production sub-system does not know what kind of products desired by consumers so that the handling and production is not oriented to consumer desires. Another problem is producers are not aware of the final buyers of their produce. Since intermediaries hinder the visibility of the marketing channel, thereby restricting a producer's choice to that of the first intermediary (Bignebat, 2009).

Although local farmers have various limitations and problems, but they have good category of FFV quality which is supplied to Retail XYZ Group. But in terms of durability, FFV from local suppliers perceived worse than the imported FFV suppliers. This is because of a worse post-harvest handling through standardization, grading and handling. Post-harvest handling is supported by research and development facilities, especially for post-harvest technology. It is also perceived that a research and development function of FFV importer is better than local FFV suppliers.

FFV is a perishable product, and then one of the technologies used by the supplier to maintain durability FFV is packaging to protect the product from disability and easiness of storage. The use of packaging on local FFV suppliers worse than the suppliers of FFV imports. This is because it is not all local FFV using packaging and packaging when using, not all FFV use proper packaging and in accordance with the characteristics of the FFV.

Both FFV local supplier import have good knowledge about the products FFV. FFV local supplier knowledge can affect the capability of product handling of sub-system FFV production that will affect marketing sub-system. Good knowledge of the products should be backed up with FFV technology in order to obtain good quality FFV.

FFV product continuity deliver from suppliers to Retail XYZ Group can be supported by the availability of storage and easiness of storage products (size and shape). FFV availability of local suppliers has less storage space than imported FFV suppliers. FFV is supplied from local suppliers have worse storage product storage. Limitation of storage space on local FFV supplier local will impact to the limitation of FFV stock. Besides local FFV has a size and shape that does not support to storage easiness. The use of 
packaging such as cardboard and other packaging that is low, resulting in difficulties in storing and consuming large place.

Availability of FFV throughout the season either on local suppliers and suppliers FFV imports included in the qualifications bad. Although imported FFV suppliers can meet the demand quantity but not yearround availability of FFV offered. This is because in most FFV, such as fruits have characteristics that do not harvest throughout the year but harvested in a given month. Imported FFV suppliers have more accuracy in predicting the supply of products that suit the needs of the number of retailers, such as on the day of Eid, Christmas and new year imported FFV suppliers already have more inventory because knowing the day as an important day when retailers will give a higher demand.

Service supplier in the local FFV supplier has time delivery and handling complaints from the retail slower than imports. This is presumably due to the management of suppliers is still traditional and so much slow in action. FFV supplier time management poor local retailer performance because it can hinder the timely delivery is important for the retailers.

FFV price offered both by local supplier and importer is perceived in a good rating despite the higher average of import supplier. Shipping costs of both suppliers including good category rating average although higher import supplier. This shows that the price of local FFV can compete with imports. The price of local FFV is mostly affected by transportation cost. According to Setijadi (2012), the price of local products FFV expensive mainly because of high transport costs. Transportation costs include all costs to be incurred for the delivery of FFV products from production centers to markets or merchant / retailer. Percentage of transportation costs to the price of FFV is quite high. A poor FFV product handling on local suppliers is affecting to the limitation of product availability supply to the retail. Consequently of this condition is that only limited quantity of local FFV that can meet retail FFV standards quality. Hereafter, it is the cause of the increasing of local FFV price.

A special promotions given supplier FFV import is much better than the local FFV suppliers. Promotion given by the supplier is usually a bonus imported FFV with overstate the quantity of total demand. Promotion in the form of bonuses is rarely done by local supplier because the supplier is still lacking to meet the retailer demand.

The lack of knowledge and the quality of the staff working in the retailer will give negative impact to consumers (Gustafsson et al, 2009). Therefore staff should have a good knowledge of the FFV that are marketed by retailers as well as knowledge about the product handling. FFV imports and local suppliers have extensive knowledge about the product being marketed, but suppliers of imported vegetables and fruits provide technical assistance in the form of sharing and managing knowledge in dealing with a better product than the local FFV supplier.

\section{CONCLUSIONS}

Innovation is generally considered to be one of the key drivers of corporate success (Cardozo et al.1993). Keep being innovative will keep the company to be competing among the turbulence changes in business environment. In marketing, innovation is recognized to contribute significantly to extend that a firm is market driven (Hurley and Hult 1998; Manu and Sriram 1996). Market driven with costumer focus will lead the company to planning and mapping consumer willingness from a product. Especially for FFV product with less product differentiation will make the consumer easily to switch their buying to the competitor. From marketing point of view innovation is a tool to face the competition from competitors. In this competitive environment the firms can only compete either by reducing the cost or by innovation (Abrar et al., 2009). One of the important issues marketers face in this context is how to successfully market their innovations (Frambach, et.al. 1999). However, build an innovative marketing is not an easy thing to do, because it should be through a long process and it needs a sufficient and proper resource.

There are three main of common innovation determinants were identified of an organizational innovation; there are management support for an innovative culture, a customer/market focus, and a high level of internal and external communication/ networking (Read, 2000). These innovation determinants of FFV modern retail local supplier, means they need to internalize innovative behavior as their internal business culture in order to make distinction and keep competitive among their competitors. It has been found though, in the few identified studies, that there is a positive relationship between organization innovativeness and its performance (Read, 2000). Therefore, as its need to be developed for both modern retail and their FFV local supplier by means of consumer-driven in order to fulfill consumer needs and wants is by applying marketing communication innovation and then interpreted into a better marketing performance of FFV supplier.

A better and more qualified of local FFV supplier to communicate with modern retail as their buyer will increase their bargaining position in the market. Marketing communication is critically important. Local FFV suppliers should start to communicate more frequently with the buyer either by telephone, text or email. It is also approving that access to means of communication (telephone, internet) is paramount (Labaste, 2005). A good marketing communication will generate good relationship marketing. Communication in marketing relationship serves not only as persuasion tools but also to inform, to listen and to answer which requiring interaction between the communication actor as a two way communication (Duncan and Moriarty in Andersen, 2001).

According to Kotler (2000) relationship marketing is one of a concept to build a long term business 
relationship as its goal in form whether by satisfying customer and suppliers. Inter organizational processes and systems can be set up with joint goal setting, procedures and activities (Johansson, 2001). By managing customer relationship it is an opportunity to build continuous competitive advantage towards brand, product or companies comparing relatively with others (Rangkuti, 2002).

In the future there is possibility for the retail to make a direct partnership with small holders who are able to meet retail FFV requirements; this is an opportunity for the small holder to build a long term relationship marketing with modern retail. In the future this relationship could become an incremental marketing communication innovation. One of the goals by creating relationship marketing between FFV supplier and modern retail is FFV product improvement that appropriate with modern retail demand in product quantity, quality, continuity, post harvest handling, durability, research and development facility, product sourcing and availability throughout season.

In order to make a long term relationship marketing, service is one of considered complementary factor to satisfy customer. In this case, delivering service excellent through marketing communication with the modern retail as FFV supplier costumer is thru Local FFV supplier service improvement especially technical assistance which covers technical assistance concerning local FFV product knowledge characteristic and product handling. This is important especially for FFV staff of the modern retail to know well how to handle and organize local FFV. It is considered that every FFV has its own characteristics and it should be treated also in a different way. This application could be impact on local FFV quality improvement because the product will have longer display ability and it is expected to escalate local FFV product sales at the modern retail. Service excellent from local FFV supplier also should be done concerning time management in order to improve time speed and accuracy to deliver the product. Other service excellent which also can improve local FFV supplier performance is after sales service serves for the retail particularly in respond and act to every retail demand.

\section{REFERENCES}

Abdullah, Nurudin. 2003. Persaingan Ketat di Bisnis Ritel. Business Indonesia, Arah Bisnis dan Politik Pasca IMF, Sektor Riil, Oktober.

Andersen, Poulhouman. 2001. Relation Develpment and Marketing Communication: An Integrated Model. Jurnal of Business and Industrial Marketing, Vol.16 No. 3. MCB University Press.

Assauri, Sofjan. 2010. Manajemen Pemasaran (Marketing Management). Rajagrafindo Persada: Jakarta.
Bignebat, Ce 'line Ahmet Ali Koc \& Sylvaine Lemeilleur. 2009. Small holder, supermarkets, and the role of intermediaries in Turkey's fresh fruit and vegetable market. Agricultural Economics, 40, 807-816.

Cardozo, Richard, Karen McLaughlin, Brian Harmon, Paul Reynolds \& Brenda Miller, Product-Market Choices and Growth of New Businesses, Journal of Product Innovation Management (1993), 10, 331- 340 .

Frambach, Rudd T, et al. 1999. Organizational Innovation Adoption: A multi Level Framework of Determinants and Opportunities for Future Research. ISBM Report 29-1999: Institute for The Study of Business Markets The Pennsylvania State Institute.

Gustafsson et al. 2009. Retailing Logistics \& Fresh Food Packaging. London and Philadelphia: Kogan Page.

Hurley, Robert F \& Hult, Thomas G., Innovation, Market Orientation, and Organizational Learning: An Integration and Empirical Examination, Journal of Marketing, July 1998, 62, 42-54.

Johansson, Ulf. 2001. Retailers suppliers relationships in the grocery industry, School of Economics and Management Lund University: Sweden.

Kanjaya Meshvara \& Susilo, Yongky. 2010. Retail Rules. Erlangga: Jakarta.

Kohli, A. \& Jaworski, B. 1990. Market Orientation: The Construc, Research Proposition and Managerial Implications. Journal of Marketing, April, 54, 1-18.

Kotler, Phillip. 2000. Marketing management: Milenium edition. Upper Saddle River, NJ: Prentice Hall, Inc.

Kovacic et al. 2002. Segmentation of City Market Customers in Croatia - towards a marketing Strategy For Fruit and Vegetable Market. Die Bodenkultur, 53 (4), 207 - 216.

Labaste, Patrick 2005. World Bank Working Paper No. 63 The European Horticulture Market Opportunities for Sub-Saharan African Exporters. Washington: The International Bank for Reconstruction and Development/The World Bank.

Masterman, Guy and Wood, Emma H. 2005. Innovative Marketing Communications. Britain: Elsevier.

Miles, R.E \& Snow, C. C. 1987. Organizational Strategy, Structure, and Process. New York: McGraw Hill.

Abbar, Muhammad et al. 2009. Exploration of Niche Market and Innovation in Organic Textile by a Developing Country. International Journal of Business and Management, 4 (2), 10-16. 
Phillips, Jon C. \& Peterson H. Christopher. 2007. Strategic Marketing Decision for Organic Agricultural Producers. International Food and Agribusiness Management Review Volume 10, Issue 1 (IAMA).

Rangkuti, Freddy. 2002. Measuring Customer Satisfaction. Gramedia. Jakarta.

Read, Anthony. 2000. Determinants of Successful Organizational Innovation: A Review of Current Research. Journal of Management Practice, 3(1), 95-119.

Setijadi . 2012. Logistik Untuk Peningkatan Daya Saing Hortikultura (Logistic for Horticulture Competitiveness Improvemnet). Accessed: 1 November 2012.http://www.supplychainindonesia. com/logistik-untuk-peningkatan-daya-sainghortikultura/.

Sophiah, Shyihabudhin, 2008. Manajemen Bisnis Ritel (Business Retail Management). ANDI: Yogyakarta.
Stokes, David. 2000. Putting Enterpreneurship into Marketing: 1-16. Journal of Reseacrh in Marketing \& Enterpreneurship, 2(1).

Pandin. Marina R. L. 2009. The Portrait of Retail Business in Indonesia: Modern Market. Economic Review, 215, 1 - 11 .

Perdana, Tomy. 2009. Management of Supply Chain to Fulfill Horticultural Export Markets. Workshop on Development of Supply Chain Management Horticulture Export Oriented Market. Bandung.

Porcu. Lucia, et.al. 2012. How Integrated Marketing Communication Works? A Theorithical Review and an Analysis of Its Main Drivers and Effects. Comunicacio Y Sociedad, Vol.XXV, Num.1, 313-348.

Traill, W. Bruce \& Meulenberg, Matthew. 2002. Innovation in the Food Industry. Wiley Periodicals Journal Agribusiness, 18 (1).1-21.

Rangkuti, Fahwani Y and Slette, Jonn. 2010. Indonesia Retail Food Sector: Retail Report Update. GAIN Report No. ID1001. USDA Foreign Agricultural Service. 